\title{
Realistic Reflection of Cultivating Way on College Students' Socialist Core Values
}

\author{
Minghui Li \\ College of International Exchange, Bohai University, Jinzhou, 121013, China \\ liminghui0607@sina.cn
}

Keywords: college students; socialist core values; cultivating way; realistic reflection

\begin{abstract}
Socialist core values education has certainly abstract and dull, results in the decrease of students' interest and enthusiasm of learning. In this paper based on the theory of socialist core values and the theory of path dependence, combing socialist values cultivating ways of students, analyzing the existing problems and profound reflection on the existing way, putting forward solutions, so providing guidance for the college students' socialist values. Currently, the main way including the four aspects, that is classroom teaching, practice teaching, the network platform and regulations. The specific solutions are putted forward including path integration and innovation, the construction of ideology discourse dominance, concise socialist core values agree with college students.
\end{abstract}

\section{Introduction}

Values are the umbrella name of the basic method and basic idea which formed in the process of knowing the world and transforming the world, it is characterized by value goal, also showed the value scale. Marxism believe that values are formed in basis material of the era, once the values formed, it has relative independence and historical inheritance, and over a longer period of time, it has relatively stable, and determines the behavior patterns and behavior of the individual goal [1]. The correct socialist core values can form a strong cohesion and a strong sense of collective consciousness, national consciousness, national awareness, and show the active spirit. Cultivation of socialist core values is the important foundation to realize the great Chinese dream, is the realization of the power source of the contemporary college students value [2]. College students is the main source of high-level personnel, is the fresh troop for the development of socialist economic and society and the construction of an innovative country. The university stage is the final stage before college students towards the society, the values of this phase with strong plasticity, good values of the college students concerns their personal value and social value after entering society. How to cultivate and practice the socialist core values, and the socialist core values into the whole process of the ideological and political education and college students quality cultivation and guide the ideological behavior along the socialist direction, the ideological and political education workers is facing an urgent task. Socialist values of students, cultivating ways, find out the existing problems, and to provide guidance for the corresponding cultivation strategies.

\section{Theoretical Basis of Socialist Core Values}

Theoretical basis is refers to the basic concept and category of a discipline, judgement and inference. Is the science theory system plays a fundamental role, and have the characteristics of stability, fundamental and universal theory principle. Socialist core values of theoretical basis including Marxist theory, the theory of socialism with Chinese characteristics and Chinese excellent traditional culture [3-7].

(1) The Marxist theory. Marxism is a kind of socialism ideological system, by the Marxist political economics, dialectical materialism and historical materialism, and three main components of scientific socialism. Marxism is the beacon to the proletariat liberation, with communism as the ultimate pursuit of ideal society, in the new democratic revolution, socialist revolution and socialist construction in the process of constantly prove its correctness and guiding significance. The 
socialist core values is Marxism, Mao Zedong thought and theoretical system of socialism with Chinese characteristics the value embodiment and expression, is the core values of Marxism, is the latest achievements of sinicization of Marxism. Socialist core values in essence is the evolution and development of Marxist theory in China. Therefore, the theoretical foundation of the socialist core values is the most important is Marxism, especially Marxist ideological theory, theory of human nature, social development theory and the theory of education system. Marx ideology theory, basic views include three aspects, social material life practice is the existence of ideological foundation, ideology as "soft state" is a tool of class rule, the carrier of ideology is the class society culture development. The socialist core value system is the essence of socialist ideology reflected, is a common ideological basis of the united struggle of the Chinese people of all ethnic groups. Essence is a socialist country of "institutionalized ideology" and "ideology state apparatus", is the national important "soft power"; Marxism think that the essence of man is the sum of all social relations, from the labor and the social relations of people scientifically reveals the essence of man. The essence of man is not innate, but formed in the social practice. Social relationships are changing, therefore, the essence of man changes with the change of the social relations; The Marxism social development impetus theory, which is in critically inherited the traditional western social development impetus theory formed on the basis of reasonable ingredients, scientifically reveals the impetus to promote the development of society, realized the transcendence of predecessors about the thought about the power of social development achievements; Marxism education theory as the guiding ideology of the development of education enterprise in our country, for the healthy development of the education has played an important role. In the new historical period, the education development of politics, economy, culture and so on great changes have taken place in the external conditions, therefore, to absorb the latest achievements of civilization and education results, looking for theoretical innovation points from theory and practice, be good at to attribute theory and abstract of new experience, new Marxist education theory practice meaning and existence value.

(2) The theory of socialism with Chinese characteristics. System of theories of socialism with Chinese characteristics and the system of socialist core values is to guide the construction of the party's new idea, highlighting the new awakening of the Chinese communist party's ruling consciousness, make the deeper of the communist party of China highlights the new connotation of Marxist development. System of theories of socialism with Chinese characteristics and socialist core values has the theoretical character of keeping pace with The Times, reflected the general laws of development of modern society, reveals the root of the development direction of the communist party of China. Has the following characteristics: the system of theories of socialism and the socialist core values is changing, both have strong attribute of times; Socialist theory system and the socialist core values is rich and colorful, both with strong universal color; Theoretical system of socialism and the socialist core values is two dimensional promotion, both with strong implicit value. The great practice of socialism with Chinese characteristics gave birth to the socialist core values. The socialist core values is the essence of socialist ideology, originates from the practice of socialism with Chinese characteristics and guide the practice. And with the development of the practice of socialism with Chinese characteristics and continuous development.

(3) Chinese excellent traditional culture. Socialist core values in the absorption of Chinese excellent traditional culture on the basis of abundant nutrition gradually development and perfection, is the continuation of Chinese excellent traditional culture in modern society, both in is unity. Chinese excellent traditional culture is the deep fertile soil of socialist core values, leave the excellent traditional culture of nourishing, socialist core values will become, like water without source. The socialist core values embodies the inheritance and sublimation of Chinese excellent traditional culture, to cultivate and carry forward Chinese excellent traditional culture plays an important role in practice of socialist core values. China is in a critical period of comprehensively deepen reform, there are many contradictions and problems, education, guide students to set up the correct values about the fate of the country and the people's vital interests. Should be correct understanding of Chinese excellent traditional culture and the relationship of socialist core values, 
vigorously carry forward the Chinese excellent traditional culture, promote the cultivation and practice of socialist core values.

\section{Analysis on Path Dependence Theory}

Path dependence refers to economic, social or technology such as system once in a path, will be under the action of inertial self-reinforcing unceasingly, and locking in a particular path. Path dependence theory was first made by the United States economic historian Paul a. David, after w. Brian Arthur and Douglas North scholars such as development, widely used in political science, sociology, economics, management and other disciplines, and become an important theoretical understanding of social and economic system evolution [8].

Path dependence theory in the countries have realistic significance in the process of the economic system transformation. Economy is a major transformation process of institutional change, the process has the characteristics of path dependence. First, the choice of the initial system provides strengthening stimulation and inertia of the existing system, because the original system change path and established the direction forward, the more convenient than another path to some; Second, a system form, have a vested interest in the existing system can be formed pressure group, to consolidate the existing system, hinder the further change, even if the new system is more efficient than the existing system. Even if for some reason to accept further reform, will strive to make the change to consolidate and expand their vested interests. Reform success depends not only on the subjective desire of the reformers and the established target schema, and depends on the start of the selected path. Therefore, made any decision, a reform should not only consider the is going to take direct effect of decision-making, the long effect; Reform to study at any time if be not the correct path, if found the path deviation to take measures to correct as soon as possible, back to the correct track, in order to avoid the legacy of conditions.

In practice training of socialist core values of college students, the choice of the path must be doubly cautious. To seriously study the feasibility and scientific nature of original path, and changes in view of the current student development and characteristics of body and mind to make timely adjustment and innovation. Otherwise, it is easier for colleges and universities to carry out the core values into a path choice dislocation, path information, the wrong layer interaction of the actual effect is not obvious in the cultivation of the core values.

\section{Main Cultivating Way on College Students' Socialist Core Values}

After reviewing the related literature, based on field surveys and at present the main way to cultivate college students' socialist core values is as follows [9-11]:

(1) The classroom teaching. The current college students the channels and ways of socialist core values education is relatively narrow, the classroom is still the major site of socialist core values education. Teachers need to mobilize students' learning initiative and enthusiasm, correct students' awareness and enable students to actively participate in the socialist core values in the learning process. Need a proper evaluation of ideological and political course of change, through a more effective monitoring and management to improve the students' importance, let the students can become more serious in the face of the socialist core values education, stimulate students' learning enthusiasm. In the process of classroom teaching with diversified teaching methods to carry out the socialist core values education, full of vitality and fun, to improve teaching quality and efficiency.

(2) Social practice. Social practice is an important part of the ideological and political education of college students is the important way of socialist core values education. Social practice to promote college students' understanding of the society, understand the national conditions, growth ability, contributing to society, exercise perseverance, cultivate our character, and strengthen social responsibility have an irreplaceable role. The social practice into the overall teaching plan and teaching outline, regulation and credit hours, provide the necessary funds. Actively explore and establish the social practice and specialized study, combined with a social service, combining with the work-study combination, combined with choosing employment, entrepreneurship and 
innovation with the combination of management system, enhance the effect of social practice activities, students' concept of labor and professional ethics.

(3) The network platform. Network has become the university to consolidate and strengthen campus culture construction and innovation and the important means of ideological and political education work. Socialist core values into the open network platform is the "cultivating people", "how to cultivate people" new strategic issues. Through the network platform to discuss and exchange, which is beneficial to the network under the condition of deepening and the implementation of "arming people with scientific theory, in the right public opinion guide people with lofty ideals, and inspire them with excellent works of literature and art" of the strategic mission, strengthen college students' socialist core values education of radiation, the attraction and appeal, in leading combined with penetration, enlightenment and inspiration, the combination of feeling and practice process, the combination of optimization of college students' socialist core values education results.

(4) The system specifications. Systems generally refers to the act of the request everyone abide by rules or principles, action also refers to in a certain historical conditions to form the statute, custom specifications or some other specifications. Different industries have different systems, the purpose is to make each work plan according to the requirements to achieve the expected goals. System on the premise that obedience and coercive power to regulate and guide, punishment, etc. As the change of The Times, especially in the period of social transition, the ideas of people increasingly diversified, need more system to regulate people's behavior. If individual students' ideology and behavior does not accord with the core values, then need to use the rules regulating the behavior of college students, the core values of make it toward the right direction.

\section{Realistic Reflection of Cultivating Way on College Students' Socialist Core Values}

Values cultivation is a complicated system engineering, and the complexity of the contemporary college students' physical and mental qualities, more let breeding difficult complex of socialist core values. According to the path dependence theory analysis and the main way at present, there are the following points need to reflect on $[12,13]$ :

(1) Path integration and innovation. Path dependence is a scientific frontier problem, enrich the understanding of the objective world development evolution law. Path dependence on the discovery of scientific theory, guiding people to practice by blind become conscious, by the unconscious conscious. System to develop, must always pay attention to look at the routing problem, must carry out integration and innovation. Integration is to put some scattered in some way to connect with each other, so as to realize the resource sharing and collaborative work of system, main essence is the scattered elements together, and eventually form a valuable efficient as a whole. Innovation is the innovation under the limit, the possibility of path innovation has a broad development space. Integration and innovation can be mainly from three aspects, highly integrated the advantage of cultivating path the main body of socialist core values, in-depth excavation of socialist core values cultivating path object resources, vigorously promoting the socialist core values to foster the generation of path integration.

(2) Build ideological discourse dominance. Marxist ideology discourse, it is to point to based on social status control and guide, or specification, with the value judgment of ideology and theory perspective, dominant or guide social problems. As people thought core values, is the formation and development in a certain ideological environment. In cultivating college students' socialist core values to grasp ideological discourse dominance, is the current multiple ideological exchange, exchange, a core element in communion. Constructing ideology discourse dominance is effective way to cultivate college students' socialist core values, mainly includes the following three aspects: from a perspective of micro in everyday life, cultivating college students' socialist core values, the ideological and political theory course and organic combine, attach importance to students' daily life practice in college students' cultivation of socialist core values in the network space.

(3) The concise core values agree with college students. Cultivating and practicing the socialist core values is the premise of identification, identification of effective way is to make it specific, 
visualization, and life. College students of socialist core values is the degree of identity and identity, is directly related to the country's future direction, the development of the society to the talents, character and belief formation of trend. College students to know, love is the identity of socialist core values, the dialectical unification process, generally go through three stages: cognitive identity, master the core values of theory knowledge, understand the historical process of the formation of the core values, grasp the cultural essence of core values contained; Emotion recognition, is the intermediate links, which forms a connecting link between the preceding values identity is deepening, cognitive identity and behavior identity emotional foundation; Behavior identity, the core values as a code of conduct and guidelines, and commitment to the implementation.

\section{Conclusion}

The socialist core values is the product of socialist development, is an advanced scientific ideology. As a special social group, college students have higher cultural quality, are the important force to promote the development of social progress. To strengthen the socialist core values education has important theoretical significance and practical significance for college students to enter society effectively achieve their personal value and social value. Cultivation of socialist core values is the important foundation to realize the great Chinese dream, is the realization of the power source of the value of contemporary college students. Socialist core values education itself has certainly abstract and dull, results in the decrease of students' learning interest and enthusiasm. In the limitation of the existing cultivating ways and conditions, teachers cannot express the true connotation of socialist core values and intuitive expression, so cannot let the student to obtain in-depth understanding of it. The research achievements of this paper was applied to cultivate college students' socialist core values, and will play a positive role.

\section{Acknowledgement}

This work is supported by social science fund project of Liaoning province (L15BSZ021): Cultivation Strategy on College Students' Socialist Core Values in Multicultural Perspective

\section{References}

[1] H. L. Li, "On the cultivation of College Students' socialist core values in the new period: Take Baoding College as an example," School party construction and Ideological Education, vol. 33, no. 13, pp. 47-48, 2015.

[2] P. Xu, "Cultivation path innovation of College Students' socialist core values," China Adult Education, vol. 34, no. 6, pp. 37-39, 2015.

[3] Z. Q. Liu, "Study on theoretical basis of socialist core values," New West, vol. 15, no. 20, pp. 7-8, 2014.

[4] Y. Che, W. Y. ZHang, "Marx's theory foundation of accept research on socialist core values," Henan Education, vol. 10, no. 9, pp. 20-21, 2014.

[5] R. N. Kong, "On the theoretical basis of the socialist core values: Study on Wang Yuliang's philosophy of value," Tangdu Journal, vol. 31, no. 4, pp. 69-70, 2015.

[6] L. Yang, L. Y. Fu, "Refining the core values of socialism based on the practice of socialism with Chinese characteristics," Literature on Party Building, vol. 31, no. 12, pp. 59-60, 2012.

[7] N. Q. Song, "Socialist core values and Chinese traditional culture," Guangming Daily, 2014-10-08.

[8] Y. M. Yin, Z. G. Liu, W. D. Liu, "Analysis on the progress of path dependence theory," Foreign Economics \& Management, vol. 33, no. 8, pp. 1-7, 2011. 
[9] K. Xiang, "On Improving College Students' socialist core values of classroom teaching," Journal of Higher Education, vol. 1, no. 7, pp. 36-37, 2015.

[10] Y. Jin, H. Z. Chen, "On Social Practice and College Students' Education of Socialist Core Values," Journal of Hebei Normal University for Nationalities, vol. 34, no. 4, pp. 101-104, 2014.

[11] Z. M. Han, "Education of College Students' socialist core values based on the network culture platform," Legality Vision, vol. 31, no. 22, pp. 46-47, 2015.

[12] J. G. Peng, X. Zhou, "Ideological discourse power: challenges and paths of the cultivation of College Students' socialist core values," Studies in Ideological Education, vol. 27, no. 1, pp. 36-39, 2014.

[13] W. X. Gao, H. L. Fang, "College Students' core values: concise and effective way to cultivate and practice the socialist core values," School party construction and Ideological Education, vol. 31, no. 10, pp. 11-12, 2013. 